\title{
Cadmium removal by living cells of the marine microalga Tetraselmis suecica
}

Mónica Pérez-Rama, Julio Abalde Alonso, Concepción Herrero López, Enrique Torres Vaamonde ${ }^{1}$,

Bioresource Technology, Volume 84, Issue 3, September 2002, Pages 265-270

Received 1 November 2001, Revised 15 January 2002, Accepted 29 January 2002, Available

online 18 March 2002

DOI: 10.1016/S0960-8524(02)00045-7

\section{Abstract}

Cadmium removal by living cells of the marine microalga Tetraselmis suecica was tested in cultures exposed to different cadmium concentrations (0.6, 3, 6, 15, 30 and $45 \mathrm{mg} / \mathrm{l})$. The EC50 for growth was $7.9 \mathrm{mg} \mathrm{Cd} / \mathrm{l}$ after six days of exposure. The cadmium removed was proportional to the concentration of this metal in the medium and it was dependent on the time of exposure; cultures with higher cadmium concentration removed a higher amount of this metal. In cultures exposed to $0.6 \mathrm{mg} / \mathrm{l}, \mathrm{T}$. suecicacells removed $98.1 \%$ of added cadmium

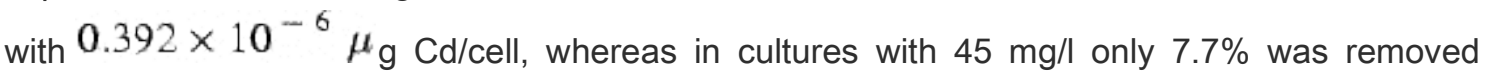

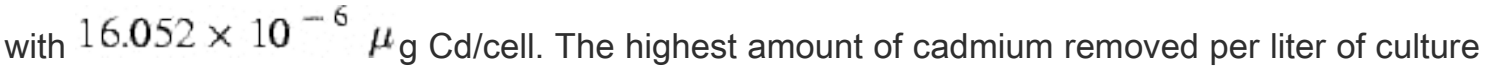
was observed in cultures exposed to $6 \mathrm{mg} / \mathrm{l}$, with $3.577 \mathrm{mg} / \mathrm{l}$ of cadmium. After six days of incubation, the higher proportion of cadmium was bioaccumulated intracellularly in all cultures except in $45 \mathrm{mg} / \mathrm{l}$ cultures, the percentage of intracellular cadmium being always more than $50 \%$. The highest percentage of bioadsorbed cadmium (60.1\%) was found in cells of cultures with the highest cadmium concentration $(45 \mathrm{mg} / \mathrm{l})$. Furthermore, a relation between intracellular cadmium and the concentration of sulfhydryl groups was observed.

\section{Keywords}

Microalga; Tetraselmis suecica; Cadmium removal; Bioaccumulation; Biosorption; Sulfhydryl groups

\section{Introduction}

Metal pollution of environments is one of the major problems of increasing magnitude. In this way, metal pollution can produce many biological effects on aquatic environments. These biological effects may result in structural changes in planktonic communities. In particular, they

\footnotetext{
${ }^{1}$ Facultad de Ciencias, Departamento de Biología Celular y Molecular, Laboratorio de Microbiología, Universidade da Coruña, Campus da Zapateira s/n, 15071 La Coruña, Spain
} 
reduce the richness of microalgal species, the microalgal production and alter the microalgal community structure (Rai et al., 1981). The toxic effect of metals on microalgae is relevant since these organisms constitute the base of the marine food chain. Metals exert their harmful effects in many ways, although all the major mechanisms of toxicity are a consequence of the strong coordinating properties of metal ions that affect the properties of many biological molecules (enzymes, etc.) (Kneer and Zenk, 1992). Moreover, metals are accumulated throughout the food chain, posing a serious threat to human health.

One of the metals whose concentration is increasing in environments is cadmium. This metal has been ranked as one of the major potential metal hazards with acute toxicity to terrestrial and aquatic organisms (Vymazal, 1987). Cadmium is used in different industrial processes as production of television tube phosphores, alloy preparation, metal plating, nuclear reactor shields and rods, pigments, stabilizers, batteries, etc. A high concentration of cadmium in mine drainage has also been reported. The concentration of this element occurs at ultra trace levels in natural environments, but its increasing utilization in industrial processes has led to increased levels in aquatic environments (Mislin and Ravera, 1986). This observation has created the necessity for the development of techniques to remove this metal from the environment (Torres et al., 1998; Volesky, 1990; Vymazal, 1987).

The aim of this study was to test the ability of the marine microalga Tetraselmis suecica to remove cadmium. This microalga is easy to culture, usually used in aquaculture systems, and has shown high tolerance to cadmium toxicity.

\section{Methods}

\subsection{T. suecica culture conditions}

The marine microalga $T$. suecica (Kylin) Butch was cultured for six days in natural enriched seawater media containing several concentrations of $\mathrm{CdCl}_{2}$. The seawater was passed through a $0.45 \mu \mathrm{m}$-pore Millipore filter and a charcoal column to eliminate organic chelating substances and subsequently sterilized at $121{ }^{\circ} \mathrm{C}$ for $20 \mathrm{~min}$. The assay was carried out in this natural seawater with the addition of inorganic nutrients ( Fábregas et al., 1986) but without EDTA and Tris. The salinity of seawater was $35 \%$ and the initial pH of the culture was 7.8 .

A stock solution of cadmium was prepared by dilution of $\mathrm{CdCl}_{2}$ in Milli-Q water to a final concentration of $10 \mathrm{~g} / \mathrm{l}$ of cadmium. For the experiments, appropriate volumes of the stock solution were added to the seawater media to obtain cadmium concentrations of $0.6,3,6,15$, 30 and $45 \mathrm{mg} / \mathrm{l}$.

Cultures were carried out in 2 I glass bottles (PYREX). The bottles were previously rinsed with nitric acid and several times with Milli-Q water. Inside these bottles, the enriched seawater and an appropriate volume of the stock solution of cadmium were placed with the $T$. suecica cells at an initial cell density of $25 \times 10^{4} \mathrm{cells} / \mathrm{ml}$. Control cultures without cadmium were included. Each experiment was carried out in triplicate. Cultures were maintained at $18 \pm 1{ }^{\circ} \mathrm{C}$ under a light 
intensity of $68 \mu \mathrm{E} / \mathrm{m}^{2} / \mathrm{s}$ using cool fluorescent light and with a dark:light cycle of 12:12 h. Natural sterile air was constantly bubbled at a flow rate of $10 \mathrm{l} / \mathrm{min}$.

\subsection{Growth measure}

Growth of microalgal cultures was measured daily by counting culture aliquots in a Neubauer hemocytometer chamber after fixation with Lugol. The degree of growth inhibition by cadmium in $T$. suecica cells was measured on the sixth day. For that, the EC50 (cadmium concentration which reduces the population growth to $50 \%$ of the control) was determined by probit analysis on this day from the percentages of growth inhibition at different cadmium concentrations ( Finney, 1964).

\subsection{Extraction and detection of non-protein sulfhydryl groups-rich compound in crude extracts}

Cells from control cultures not exposed to cadmium and exposed to different concentrations of this metal were collected daily by centrifugation $(4000 \times g$ for $5 \mathrm{~min})$ and washed with metal-free seawater. The cell pellet was resuspended in $0.1 \mathrm{~N} \mathrm{HCl}$ and the cells were homogenized with an ultrasonic cell disrupter for $3 \mathrm{~min}$ at $14 \mu \mathrm{m}$. Cellular debris was removed by centrifugation at $12000 \times g$ for $15 \mathrm{~min}$ at $4{ }^{\circ} \mathrm{C}$.

Non-protein sulfhydryl groups-rich compounds were determined in these acid crude extracts by the method of Ellman (1959). An aliquot of $400 \mu \mathrm{l}$ of the acid extract was mixed with $700 \mu \mathrm{l}$ of a solution containing $10 \mathrm{mM}$ dithiobis-nitrobenzoic acid (DTNB, Ellman reagent) and $1 \mathrm{mM}$ EDTA in $0.5 \mathrm{M}$ sodium phosphate buffer, $\mathrm{pH}=7.5$. After $10 \mathrm{~min}$ of reaction in darkness, the absorption was recorded at $412 \mathrm{~nm}$. Values were corrected for the absorbance of the reagents and of the extracts.

Glutathione was used as a suitable calibrating substance for quantifying the sulfhydryl groups.

\subsection{Determination of cadmium removed}

The cadmium removed by the microalga $T$. suecica was evaluated using a modified method described by Stauber and Florence (1985).

Total cadmium in cells was determined by filtration of $15 \mathrm{ml}$ aliquots from each culture of $T$. suecica. Each aliquot was filtered through two superposed $1.2 \mu \mathrm{m}$ MF-Millipore filters. Filters were separately digested for $24 \mathrm{~h}$ with $1 \mathrm{ml}$ of $15 \mathrm{M} \mathrm{HNO}_{3}$ and $0.5 \mathrm{ml} \mathrm{HClO}_{4}$. Cadmium was measured in both filters and the lower filter was used as blank.

Intracellular cadmium was measured in the following way. A $25 \mathrm{ml}$ aliquot from each microalgal culture was centrifuged at $4000 \times g$ for $5 \mathrm{~min}$, the pellet was resuspended for $20 \mathrm{~min}$ in $25 \mathrm{ml}$ of a solution containing $0.02 \mathrm{M}$ EDTA dissolved in seawater. Afterwards, cells were centrifuged and washed twice with seawater. The EDTA washing removed cadmium adsorbed onto the cell surface, thereby allowing only intracellular cadmium to be measured. The washed pellet was digested as in total cadmium determination. 
Digested samples were brought to final volume of $5 \mathrm{ml}$ with Milli-Q water. Cadmium present in the samples was measured by ICP-MS using a VG Elemental Plasma Quad 2 ICP-MS System (VG Elemental, 63069 Offenbach, Germany).

Cadmium bioadsorbed onto the cell surface was determined by subtracting the intracellular cadmium concentration from the total cadmium removed (bioadsorbed cadmium=total cadmium - intracellular cadmium).

All determinations were made daily for six days and on day 0 the measures were taken after the addition of the inoculum of $T$. suecica to each culture.

The cadmium removal percentage (\%) was calculated on the basis of cadmium added to each culture.

\section{Results}

\subsection{Growth}

There was growth inhibition in cultures exposed to cadmium. ANOVA test $(p<0.001)$ showed that this metal had a significant effect on growth of $T$. suecica after six days of exposure. The inhibition was proportional to cadmium concentration: as cadmium concentration increased in the medium, growth decreased. Cultures with cadmium concentrations of 15 and $30 \mathrm{mg} \mathrm{Cd} / \mathrm{l}$ hardly grew, and in those with the highest cadmium concentration assayed $(45 \mathrm{mg} / \mathrm{l})$ total inhibition of growth was observed. Duncan test $(\alpha=0.005)$ showed that all assayed concentrations of cadmium inhibited growth of $T$. suecica, a significant effect on growth being observed even at the lowest concentration, $0.6 \mathrm{mg} \mathrm{Cd} / \mathrm{l}$.

The effective concentration (EC50 value) for this microalga was estimated as $7.9 \pm 1 \mathrm{mg} / \mathrm{l}$ of cadmium after six days of exposure to this metal.

\subsection{Time course of sulfhydryl groups}

The changes with time of sulfhydryl groups in cultures exposed to the different cadmium concentrations and in control cultures during the six days showed that the amount of sulfhydryl groups was proportional to the initial cadmium concentration: the greatest increase in sulfhydryl groups per cell was found in cultures containing the higher cadmium concentrations $(15,30$ and $45 \mathrm{mg} / \mathrm{l})$. In all cultures, sulfhydryl groups increased during all days of culture. Sulfhydryl groups were most abundant in cultures of $45 \mathrm{mg} \mathrm{Cd} / \mathrm{l}$ with $1.168 \times 10^{-13} \mathrm{~mol}-\mathrm{SH} / \mathrm{cell}$ on the sixth day. The other cultures $(0.6,3,6,15$ and $30 \mathrm{mg} / \mathrm{l})$ reached a maximum amount of $1.463 \times 10^{-15}, 1.094$ $\times 10^{-14}, 2.220 \times 10^{-14}, 7.350 \times 10^{-14}$ and $8.726 \times 10^{-14} \mathrm{~mol}-\mathrm{SH} /$ cell, respectively.

\subsection{Removed cadmium}


T. suecica is a marine unicellular microalga whose cells are able to bioaccumulate and bioabsorb cadmium, allowing it to be removed from the medium. These cells showed a high ability for cadmium removal.

The total cadmium removed per cell was significant from the first day of culture. In all cultures, T. suecicashowed a rapid accumulation of cadmium in the first two days. The amount of cadmium removed in most cultures reached a maximum after two or three days of exposure to the metal, and thereafter, a decrease was observed. The highest value of metal removed occurred in cultures with the highest cadmium concentration assayed (45 mg Cd/l) and on the fifth day of culture $\left(16.052 \times 10^{-6} \mu \mathrm{g} / \mathrm{cell}\right)$. In cultures with the lowest cadmium concentration assayed $(0.6 \mathrm{mg} / \mathrm{l})$ the maximum amount of cadmium removed by cells was $0.392 \times 10^{-6} \mathrm{\mu g} / \mathrm{cell}$ on the third day of culture. In the other cultures $(3,6,15,30$ and $45 \mathrm{mg} / \mathrm{l})$ the maximum amount of cadmium removed from the medium was $1.769 \times 10^{-6}, 3.49 \times 10^{-6}, 6.784 \times 10^{-6}, 10.655 \times 10^{-6}$ and $16.052 \times 10^{-6} \mu \mathrm{g} /$ cell, respectively. Total cadmium removed by the cells increased as cadmium concentration in the medium increased.

Part of the total cadmium removed by cells was accumulated intracellularly and another part was adsorbed onto the cell surface.

The amount of cadmium removed intracellularly increased as cadmium increased in the medium and with time of exposure. In cultures with the lower cadmium concentrations $(0.6,3$ and $6 \mathrm{mg}$ $\mathrm{Cd} / \mathrm{l})$ this increase was more gradual from the third day of culture. The maximum amount of cadmium removed intracellularly was $6.260 \times 10^{-6} \mathrm{\mu g} / \mathrm{cell}$ in cultures exposed to $45 \mathrm{mg} \mathrm{Cd} / \mathrm{l}$ and after six days of culture. In cultures exposed to $0.6 \mathrm{mg} \mathrm{Cd} / \mathrm{l}$ the uptake of cadmium reached a value of $0.217 \times 10^{-6} \mathrm{\mu g} / \mathrm{cell}$ in six days. In the rest of the cultures exposed to the cadmium concentrations assayed $(3,6,15$ and $30 \mathrm{mg} / \mathrm{l})$ the maximum amounts of cadmium removed by bioaccumulation into $T$. suecica cells were $0.834 \times 10^{-6}, 1.889 \times 10^{-6}, 4.231 \times 10^{-6}$ and $4.883 \times 10^{-6} \mu$ g/cell, respectively.

During the six days of culture and for all cadmium concentrations assayed there was a rapid increase in the cadmium adsorbed on the cell surface during the first two days of exposure. From the second day on, cadmium adsorbed decreased in all cultures. The maximum amount of cadmium removed by adsorption to the cell surface was in cultures exposed to the highest cadmium concentration ( $45 \mathrm{mg} / \mathrm{l})$ with $13.254 \times 10^{-6} \mu \mathrm{g} / \mathrm{cell}$ on the second day of culture. Cultures exposed to $0.6 \mathrm{mg} \mathrm{Cd} / \mathrm{l}$ removed $0.199 \times 10^{-6} \mathrm{\mu g} / \mathrm{cell}$ after three days of culture. The rest of cultures $(3,6,15$ and $30 \mathrm{mg} / \mathrm{l})$ removed $1.098 \times 10^{-6}, 2.146 \times 10^{-6}, 4.812 \times 10^{-6}$ and $8.916 \times 10^{-6} \mu$ g/cell, respectively, after two days of culture.

Table 1 shows the cadmium removed from each culture after six days. The highest amount of intracellular cadmium was $2.318 \mathrm{mg} \mathrm{Cd} / \mathrm{l}$ in the cultures exposed to $6 \mathrm{mg} \mathrm{Cd} / \mathrm{l}$. However, bioadsorbed cadmium was higher in cultures exposed to the highest cadmium concentration assayed (45 mg/l) with $2.085 \mathrm{mg} / \mathrm{l}$.

Table 1.

Cadmium removed $(\mathrm{mg} / \mathrm{l})$ by the sixth day in cultures of $T$. suecica exposed to different cadmium concentrations 


\begin{tabular}{|l|l|l|}
$\begin{array}{l}\text { Initial cadmium concentrations added } \\
\text { to the cultures }(\mathrm{mg} / \mathrm{l})\end{array}$ & $\begin{array}{l}\text { Intracellular } \\
\text { cadmium }\end{array}$ & $\begin{array}{l}\text { Bioadsorbed cadmium on } \\
\text { cell surface }\end{array}$ \\
\hline Control & $0.0 \pm 0.00$ & $0.0 \pm 0.00$ \\
\hline 0.6 & $0.469 \pm 0.090$ & $0.120 \pm 0.015$ \\
\hline 3 & $1.895 \pm 0.401$ & $0.450 \pm 0.026$ \\
\hline 6 & $2.318 \pm 0.403$ & $1.259 \pm 0.115$ \\
\hline 15 & $1.667 \pm 0.386$ & $1.005 \pm 0.187$ \\
\hline 30 & $1.689 \pm 0.302$ & $1.663 \pm 0.379$ \\
\hline 45 & $1.383 \pm 0.204$ & $2.085 \pm 0.401$ \\
\hline IS.D. $(n=3)$. & & \\
\hline
\end{tabular}

Fig. 1 shows the relation between intracellular cadmium and the sulfhydryl groups on the sixth day of culture. This figure indicates that the correlation between the intracellular cadmium and the content of sulfhydryl groups was highly significant $\left(R^{2}=0.996, p \leqslant 0.001\right)$. The slope of the regression line was 2.16 , which indicates that the ratio between sulfhydryl groups and cadmium was 2 , just as expected from this type of interaction.

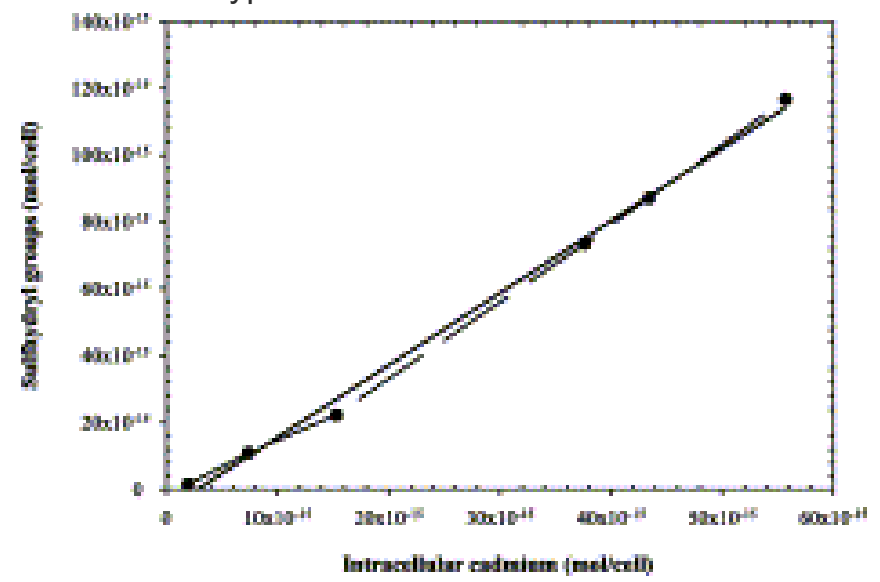

Fig. 1.

Concentration of sulfhydryl groups in $T$. suecica cells as a function of the concentration of intracellular cadmium on the sixth day of culture.

\section{Discussion}

Cadmium is one of the most toxic metals with no described biological function. This metal can produce serious hazards to aquatic organisms, including microalgae. T. suecicagrowth was inhibited in cultures exposed to cadmium. However, the effective concentration value (EC50) for this microalga was $7.9 \mathrm{mg} \mathrm{Cd} / \mathrm{l}$ after six days of metal exposure under these culture conditions. The cease-growth only happened at cadmium concentrations of $15 \mathrm{mg} / \mathrm{l}$ or higher.

Cadmium uptake by the microalgae $T$. suecica followed an initial rapid phase of uptaking during the first days of culture, reached a maximum and thereafter, there was a decrease or stabilization of the amount of total removed cadmium. Jennings and Rainbow (1979), Fernández-Leborans and Novillo (1996) and Torres et al. (1998) reported a similar pattern in Dunaliella tertiolecta, Olisthodiscus luteus and Phaeodactylum tricornutum, respectively. Total and intracellular cadmium removed per liter of medium in $6 \mathrm{mg} / \mathrm{l}$ cultures after six days of exposure was higher than in the rest of cultures. This concentration was close to the EC50 
value obtained in this assay. This is the highest cadmium concentration in which significant cell growth was observed, in spite of the toxic effect of cadmium, allowing the removal of more metal per liter of culture. The microalga growth depends on cadmium concentration in the medium, at lower cadmium concentrations the toxic effect of this metal is lower. In cultures that can reach a higher cell density the amount of cadmium removed per cell decreased as the number of cells increased. This did not occur in cultures with the higher cadmium concentrations assayed (15, 30 and $45 \mathrm{mg} / \mathrm{l})$. Practically no growth was observed in these cultures and the amount of cadmium per cell increased. A solution to removing more metal in cultures with highest concentrations would be to increase cellular biomass. Hamdy (2000) reported the effect of biomass weight on the metal uptake of different cations. They observed that cadmium removed increased when biomass of the alga Laurencia obtusa increased.

Since the addition of cadmium to cultures of T. suecica, this metal appeared bound to the cell surface. The cell wall supposes a first barrier in the uptake of the metal and plays an important role in tolerance processes to metal toxicity. This cellular structure has a common composition of carbohydrates and proteins with which the metals could react. Macfie and Welbourn (2000) reported that total amount of cadmium uptaken by a walled-strain of Chlamydomonas reinhardtii was greater than the wall-less strain after $24 \mathrm{~h}$.

Microalgae can protect themselves against metals toxicity. Different reports have shown that exclusion mechanisms and cadmium adsorption to cell surfaces seem not to be the main tolerance mechanism to cadmium. Euglena gracilis chelated and accumulated the higher amount of cadmium into the cells (Albergoni et al., 1980). In the same way, Carr et al. (1998) observed that Chlorella vulgaris accumulated the highest proportion of cadmium intracellularly. Cadmium toxicity to cellular metabolism provokes the reduction of cadmium uptake in $T$. suecica cells, and the percentage of cadmium adsorbed to cell surfaces in cultures with the highest cadmium concentrations increased, so, in the culture with the higher cadmium concentration ( $45 \mathrm{mg} / \mathrm{l}) 60.1 \%$ of the total cadmium removed was bioadsorbed. However, even in these cultures with $45 \mathrm{mg} \mathrm{Cd} / \mathrm{l}$ a high percentage of cadmium was bioaccumulated $(39.9 \%)$. Therefore, $T$. suecicamainly seems to use an internal detoxification mechanism. A common response of microalgae upon exposure to cadmium is the synthesis of intracellular metalbinding peptides that may function in detoxification of this metal. These peptides are included in the class III metallothioneins group. Cadmium is bound to -SH groups of these molecules ( Gekeler et al., 1988; Kaplan et al., 1995; Knauer et al., 1998). The increase of intracellular cadmium in $T$. suecica was in relation with sulfhydryl groups. Moreover, the ratio between the amount of sulfhydryl groups and intracellular cadmium was always close to 2 ( Fig. 1) in all cadmium concentrations assayed. In a previous study it was observed that $T$. suecica synthesized class III metallothioneins in cultures with a cadmium concentration of 6 $\mathrm{mg} / \mathrm{l}$. Metal analysis showed that about $87 \%$ of the accumulated cadmium was bound by these class III metallothioneins ( Pérez-Rama et al., 2001). In our assay, the concentration of sulfhydryl groups increased as cadmium increased in the medium, even in the higher cadmium concentrations the sulfhydryl groups increased all days of culture. This indicates that at these 
concentrations the cells are alive, and that although no growth was observed, the cells synthesized more sulfhydryl groups to tolerate the toxic effect of cadmium. Under these conditions cells can continue accumulating cadmium intracellularly in all the cultures, even in those exposed to the higher cadmium concentrations.

T. suecicawas found to have good accumulation properties for cadmium. The presence of a significant amount of this metal in its cells and the high tolerance to this metal suggested the possibility of using this microalgae in bioremediation processes in seawater polluted with cadmium. Matsunaga et al. (1999) tested 24 strains of marine microalgae for their ability for cadmium removal and they found that the marine green microalga Chlorella sp. NKG16014 showed the highest removal of cadmium with $48.7 \%$, when this microalga was exposed to $50 \mu$ $\mathrm{M}$ cadmium $(5.62 \mathrm{mg} / \mathrm{l})$ after two weeks and with a initial cell density of $5 \times 10^{7}$ cells $/ \mathrm{ml}$. In our work with $T$. suecica, this microalga removed $59.6 \%$ of cadmium when it was exposed to $6 \mathrm{mg} / \mathrm{l}$ after only six days and this percentage increased as cadmium decreased in the medium ( Table 1 ); the initial cell density used was only $25 \times 10^{4} \mathrm{cells} / \mathrm{ml}$, however it is important to take into account that $T$. suecica cells are larger than those of Chlorella sp., this fact would increase the efficiency of the removal process. Cadmium concentrations up to $6 \mathrm{mg} / \mathrm{l}$ (exactly, up to the EC50 value: $7.9 \mathrm{mg} / \mathrm{l}$ ) and with an initial cell density of $25 \times 10^{4} \mathrm{cells} / \mathrm{ml}$ living microalgal cells of $T$. suecica could act as an effective system for cadmium removal.

There has been little commercial exploitation of microalgal biosorption for metal removal or recovery processes. Both living and dead biomass can be used for metal removal. Non-living biomass has the advantage that it can be regenerated for multiple uses, but the metal is not uptaken into cells, since metals are adsorbed only at the algal surface (Fehrmann and Pohl, 1993; Torres et al., 1998). This can be a disadvantage because different reports (Matsunaga et al., 1999) and our work with $T$. suecica indicate that intracellular cadmium levels are higher than the bioadsorbed. This indicates that living biomass of these microalgal cells would be more effective for cadmium removal than non-living biomass. The feasibility of using living algae in exposed, open, water bodies for wastewater treatment has been investigated by a number of workers ( Volesky, 1990).

\section{Acknowledgements}

This work was carried out with the support of the Plan Nacional de I + D (Ref: REM 20000458HIB). M. Pérez-Rama holds a Fellowship Award from the Universidade da Coruña. We thank Servicios Generales de Apoyo a la Investigación from Universidade da Coruña, and especially to Alicia Cantarero for their assistance in ICP analysis.

\section{References}

\section{Albergoni, E. Piccini, O. Coppellotti}

Response to heavy metals in organisms-I. Excretion and accumulation of physiological and nonphysiological metals in Euglena gracilis 
Comp. Biochem. Physiol. C, 67 (1980), pp. 121-127

H.P. Carr, F.A. Cariño, M.S. Yang, M.H. Wong

Characterization of the cadmium-binding capacity of Chlorella vulgaris

Bull. Environ. Contam. Toxicol., 60 (1998), pp. 433-440

G.L. Ellman

Tissue sulfhydryl groups

Arch. Biochem. Biophys., 82 (1959), pp. 70-77

J. Fábregas, C. Herrero, B. Cabezas, J. Abalde

Biomass production and biochemical composition in mass cultures of the marine microalga Isochrysis galbana Parke at varying nutrient concentrations

Aquaculture, 53 (1986), pp. 101-113

C. Fehrmann, P. Pohl

Cadmium adsorption by the non-living biomass of microalgae grown in axenic mass culture

J. Appl. Phycol., 5 (1993), pp. 555-562

G. Fernández-Leborans, A. Novillo

Toxicity and bioaccumulation of cadmium in Olisthodiscus luteus (Raphidophyceae)

Water Res., 30 (1) (1996), pp. 57-62

D.J. Finney

Probit Analysis

Cambridge University Press, London, UK (1964)

W. Gekeler, E. Grill, E.-L. Winnnacker, M.H. Zenk

Algae sequester heavy metals via synthesis of phytochelatin complexes

Arch. Microbiol., 150 (1988), pp. 197-202

A.A. Hamdy

Biosorption of heavy metals by marine algae

Curr. Microbiol., 41 (2000), pp. 232-238

J.R. Jennings, P.S. Rainbow

Accumulation of cadmium by Dunaliella tertiolecta Butcher 
J. Plankton Res., 1 (1979), pp. 67-74

D. Kaplan, Y.M. Heimer, A. Abeliovich, P.B. Goldsbrough

Cadmium toxicity and resistance in Chlorella $\mathrm{sp}$

Plant Sci., 109 (1995), pp. 129-137

K. Knauer, B. Ahner, H. Bin Xue, L. Sigg

Metal and phytochelatin content in phytoplankton from freshwater lakes with different metal concentrations

Environ. Toxicol. Chem., 17 (12) (1998), pp. 2444-2452

R. Kneer, M.H. Zenk

Phytochelatins protect plant enzymes from heavy metals poisoning

Phytochemistry, 31 (8) (1992), pp. 2663-2667

S.M. Macfie, P.M. Welbourn

The cell wall as a barrier to uptake of metal ions in the unicellular green alga Chlamydomonas reinhardtii (Chlorophyceae)

Arch. Environ. Contam. Toxicol., 39 (2000), pp. 413-419

T. Matsunaga, H. Takeyama, T. Nakao, A. Yamazawa

Screening of marine microalgae for bioremediation of cadmium-polluted seawater

J. Biotechnol., 70 (1999), pp. 33-38

H. Mislin, O. Ravera

Cadmium in the Environment, vol. 50Birkhäuser Verlag Basel, Basel, Switzerland (1986)

M. Pérez-Rama, L.C. Herrero, A.J. Abalde, E. Torres

Class III metallothioneins in response to cadmium toxicity in the marine microalga Tetraselmis suecica (Kylin) Butch

Environ. Toxicol. Chem., 20 (9) (2001), pp. 2061-2066

L.C. Rai, J.P. Gaur, H.D. Kumar

Phycology and heavy-metal pollution

Biol. Rev., 56 (1981), pp. 99-151

J.L. Stauber, T.M. Florence

The influence of iron on copper toxicity to the marine diatom Nitzschia closterium (Ehrenberg) W. Smith 
Aquat. Toxicol., 6 (1985), pp. 297-305

E. Torres, A. Cid, C. Herrero, J. Abalde

Removal of cadmium ions by the marine diatom Phaeodactylum tricornutum Bohlin accumulation and long-term kinetics of uptake

Biores. Technol., 63 (1998), pp. 213-220

B. Volesky

Biosorption of Heavy Metals

CRC Press, Boca Raton, FL (1990)

J. Vymazal

Toxicity and accumulation of cadmium with respect of algae and cyanobacteria: a review

Tox. Assess., 2 (1987), pp. 387-415

Corresponding author. Tel.: +34-981-167000; fax: +34-981-167065

Copyright @ 2002 Elsevier Science Ltd. All rights reserved. 